\title{
Adiponectin, leptin and insulin levels at birth and in early postnatal life in neonates with hypoxic ischemic encephalopathy
}

\author{
Abdel-Azeem M. El-Mazary ${ }^{1 *}$, Khalid A. Nasif², Gehan L. Abdel-Hakeem', Tahra Sherif ${ }^{3}$, Ebtesam Farouk ${ }^{3}$
} and Ebtesam M. El-Gezawy ${ }^{3}$

\begin{abstract}
Background: Hypoxic ischemic encephalopathy (HIE) occurs in one to three per 1000 live full-term births. Fifteen to twenty percent will die in the postnatal period, and an additional $25 \%$ will develop severe and permanent neuropsychological sequalae. The control of growth and nutritional status in the fetus and neonate is a complex mechanism, in which also hormones produced by adipose tissue, such as adiponectin and leptin are involved. The aim of this study was to measure the levels of adiponectin, leptin and insulin in neonates with HIE at birth and in early postnatal life and comparing them with normal healthy AGA and SGA neonates
\end{abstract}

Methods: This study carried out on 80 full-term neonates born in Minia university hospital during the period from May 2013 to December 2014. They were divided into group I included 25 neonates with HIE and group II included 55 normal healthy neonates (30 appropriate for gestational age (AGA) and 25 small for gestational age (SGA)). Weight, length, head circumference, body mass index (BMI), glucose, adiponectin, leptin and insulin levels were measured for all neonates. Adiponectin, leptin and insulin levels were compared between neonates with HIE and normal healthy neonates as well as between AGA and SGA neonates at birth, 2nd and 6th days of life.

Results: Adiponectin and leptin levels were significantly higher at birth then began to decrease during the first postnatal week in all neonates while insulin level increased during the same period. Serum adiponectin levels were significantly lower while serum leptin and insulin levels were significantly higher in neonates with HIE than healthy neonates. In all neonates, the serum adiponectin level was positively correlated at birth with weight, length, BMI and leptin levels but not with insulin level. In neonates with HIE, serum adiponectin level was not correlated with weight, BMI, leptin level or insulin level. In all neonates, the serum leptin level was positively correlated at birth with body weight, height and BMI. In neonates with HIE serum leptin levels were not correlated with weight, BMI or insulin level after birth. There were no correlations between either leptin or adiponectin serum levels or any of the studied parameters in neonates with HIE

Conclusions: Neonates who are suffering from HIE had lower serum levels of adiponectin and higher serum levels of leptin and insulin than normal healthy neonates at birth and during the early postnatal period. The decline of leptin and increased the insulin levels after birth in all neonates may be important for the stimulation of feeding behavior and the acquisition of energy homeostasis during the early postnatal life. Positive significant correlations between adiponectin, leptin, body weight and body mass indices were present in normal healthy neonates but not in neonates with HIE reflecting the effect of hypoxia on the regulatory mechanisms controlling the adipose tissue functions.

Keywords: Adiponectin, Leptin, Insulin, SGA, AGA, Neonates, Hypoxic, Ischemic encephalopathy

\footnotetext{
* Correspondence: abdelazeemhemed@gmail.com

${ }^{1}$ Pediatric Department, Faculty of Medicine, Minia University, Minya, Egypt

Full list of author information is available at the end of the article
}

\section{Biomed Central}

(c) 2015 El-Mazary et al. Open Access This article is distributed under the terms of the Creative Commons Attribution 4.0 International License (http://creativecommons.org/licenses/by/4.0/), which permits unrestricted use, distribution, and reproduction in any medium, provided you give appropriate credit to the original author(s) and the source, provide a link to the Creative Commons license, and indicate if changes were made. The Creative Commons Public Domain Dedication waiver (http://creativecommons.org/publicdomain/zero/1.0/) applies to the data made available in this article, unless otherwise stated. 


\section{Background}

Hypoxic ischemic encephalopathy (HIE) occurs in one to three per 1000 live full-term births [1]. About 15$20 \%$ will die in the postnatal period, and an additional $25 \%$ will develop severe and permanent neuropsychological sequalae [2]. According to the latest estimates by world health organization (WHO), $98 \%$ of neonatal deaths take place in the developing countries. Perinatal asphyxia and birth injuries together contribute to almost $29 \%$ of these deaths [3]. Hormones produced by adipose tissue, such as adiponectin and leptin play a critical role in the control of energy balance in both of childhood and adult life [4]. Recent data show that children may follow different growth patterns and that those who display excessively rapid body mass index (BMI) gains may be at higher risk for adult obesity and adverse metabolic health [4, 5]. Adiponectin, a protein hormone secreted by adipose tissue, targets muscle and liver to increase uptake and catabolism of fatty acids and carbohydrates, promoting insulin sensitivity [6]. Several studies reported a positive relationship between adiponectin and birth weight $[7,8]$ but others did not [9-11].

Leptin, a hormone synthesized mainly by adipose tissue acts on the hypothalamus to convey satiety and regulate long-term energy balance [12]. There are many studies about the leptin role in energy and nutrition balance in human and mice [13-15]. It was hypothesized that children have a relative leptin resistance beneficial for their positive energy needs that occurs after birth [16].

Although, there were many studies about the effect of HIE on different tissue functions but its effect on the adipose tissue functions is not clear until now $[17,18]$.

The aim of this study was to measure the levels of adiponectin, leptin and insulin in neonates with HIE at birth and in early postnatal life and comparing them with normal healthy AGA and SGA neonates.

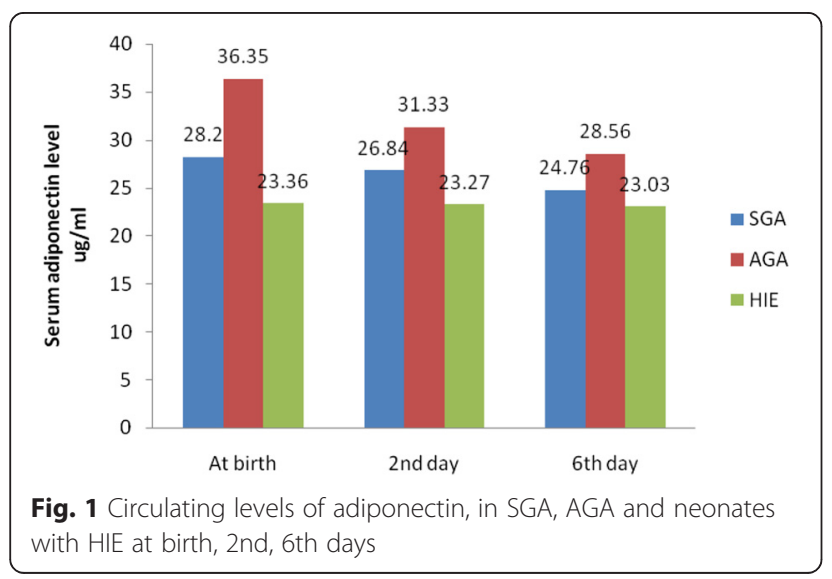

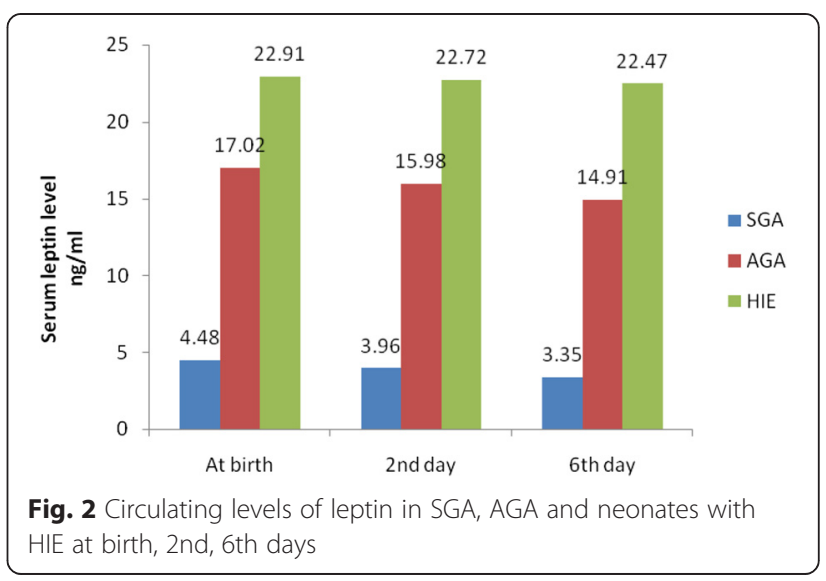

\section{Methods}

\section{Study subjects and samples collection}

A total of 80 full-term neonates (37-42 weeks) born in Minia university hospital during the period from May 2013 to December 2014 were enrolled in the study. They were divided into two groups: Group I included 25 neonates suffering from HIE and group II included 55 neonates apparently normal healthy neonates not suffering from any complications and matched with age and sex as controls (30 AGA and 25 SGA neonates).

Inclusion criteria for neonates with $\operatorname{HIE}[19,20]$ : asphyxia was defined as the presence of three or more of the following: Profound metabolic acidosis ( $\mathrm{pH}$ less than 7.00 and base deficit $\leq-12, \mathrm{mmol} / \mathrm{L}$ ) on an umbilical cord arterial blood sample, early onset of severe or moderate neonatal encephalopathy in neonates born at 37 or more weeks of gestation with neurological dysfunction including altered level of consciousness and reactivity, altered tone, hyperactive or absent reflexes, weak or absent Moro reflex and seizures, sentinel hypoxic event during labor (heart rate of less than 100 beats per minute, late decelerations, or reduced beat-to-beat variability or, severe electronic fetal monitoring abnormalities, thick meconium stained amniotic fluid and respiratory

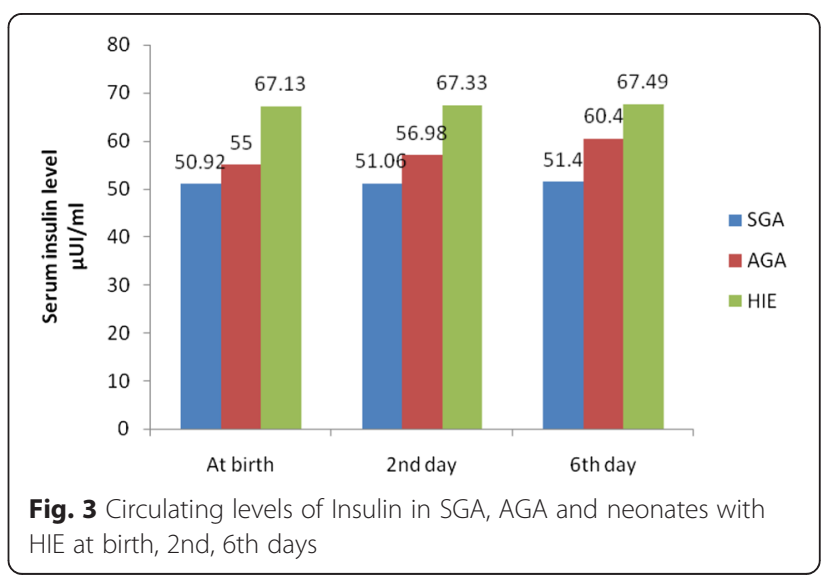


depression, hypotonia, or bradycardia, a need for resuscitation for more than 3 min with positive pressure ventilation and oxygen immediately after birth, Apgar score of 0 to 3 beyond $5 \mathrm{~min}$, onset of multisystem involvement within $72 \mathrm{~h}$ of birth and /or early imaging study showing evidence of acute non focal cerebral abnormality.

SGA was defined as body weight below $2.5 \mathrm{Kg}$. and gestational age at delivery was calculated according to last menstrual period and confirmed by ultrasound examination during the first or early second trimester.

Informed consents were obtained from all parents of neonates before inclusion in the study, for which local departmental research committee approval was obtained.

All groups were subjected to anthropometric measurements (weight, length and head circumference). Body mass index (BMI) was calculated from the formula: $\mathrm{BMI}=$ body weight $\left(\right.$ in $\mathrm{Kg}$ ) $/$ Length $\left(\right.$ in $^{2}$ )

Blood samples [3 $\mathrm{ml}$ for each sample] were obtained from all neonates within the first $24 \mathrm{~h}$, 2nd and 6th days of life. The obtained samples were centrifuged, and serum was separated immediately by centrifugation and stored at $-20{ }^{\circ} \mathrm{C}$ until assays. Neonates with evidence of malformations, genetic disorders, early onset sepsis, twins and neonates of diabetic, hypertensive or preeclamptic mothers were excluded from the study. Serum glucose was determined using auto-analyzer BM/Hitachi. Serum adiponectin concentration was assayed with an adiponectin ELISA kit (Biovendor Laboratory Medicine, Inc., Czech Republic). Serum Leptin was assayed with Human Leptin ELISA kit (DRG international, Inc., Germany). Serum Insulin was assayed with human insulin ELISA kit (BioSource Europe S.A., Belgium). For the parameters measured, the intra-assay variation was $2.7-$
$8.6 \%, 2.8-7.2 \%$ and $2.5-6.9 \%$ and inter-assay variation of $12-28 \%, 13.8-25.6 \%$ and $11.6-15.5 \%$ for adiponectin, leptin and insulin respectively. Minimum detectable concentrations (MDC) were as follows: adiponectin, 12.5 $(\mu \mathrm{g} / \mathrm{ml})$; leptin, $8.7 \mathrm{ng} / \mathrm{ml}$ and insulin, $22.4(\mu \mathrm{IU} / \mathrm{ml})$. [21-23].

\section{Statistical analysis}

The results are presented as means $\pm \mathrm{SD}$. All calculations were made using the SPSS program (version 18). Spearman correlation coefficient was used instead of Pearson $r$ correlation coefficient to compare individual changes over time. We used ANOVA test for statistical comparisons of baseline characteristics. Probability values of less than 0.05 were considered significant.

\section{Results}

Serum adiponectin concentration was significantly lower while the leptin and insulin concentrations were significantly higher in neonates with HIE than normal healthy neonates. As expected, all neonatal anthropometric measurements were higher in the AGA than SGA group. (Tables $1 \& 2$ ) and (Figures 1-3).

Insulin levels in neonates increased over the study period; they were significantly lower at birth compared to the time point's 2nd and sixth days of life. SGA circulating insulin level at birth was the lowest while HIE circulating insulin level was the highest in comparison to AGA circulating levels. At birth, 2nd and 6th days, insulin concentrations were comparable between all groups (Table 2).

Intra-group variance revealed that serum levels of adiponectin, leptin and insulin were significantly changed

Table 1 Anthropometric and laboratory data of studied groups at birth

\begin{tabular}{|c|c|c|c|c|}
\hline Item & $\begin{array}{l}\text { HIE } \\
(\text { No.25) }\end{array}$ & $\begin{array}{l}\text { SGA } \\
(\mathrm{No} .=25)\end{array}$ & $\begin{array}{l}\text { AGA } \\
(\mathrm{No} .=30)\end{array}$ & $p$-value \\
\hline Gest. Age(w) & $38.7 \pm 1.6$ & $38.8 \pm 1.6$ & $39.16 \pm 1.8$ & NS \\
\hline M/F ratio & 18(72 \%)/7(28 \%) & $19(76 \%) / 6(24 \%)$ & $22(74 \%) / 8(26 \%)$ & NS \\
\hline NVD/CS & $11(44 \%) / 14(46 \%)$ & 13(52 \%)/12(48 \%) & $16(54 \%) / 14(46 \%)$ & NS \\
\hline Weight (Kg) & $3.11 \pm 0.32$ & $1.91 \pm 0.32$ & $3.44 \pm 0.24$ & $0.001^{b}$ \\
\hline Length (cm) & $44.50 \pm 3.14$ & $42.50 \pm 3.14$ & $46.75 \pm 1.33$ & $0.01^{a}$ \\
\hline BMI (kg/m2) & $14.05 \pm 0.61$ & $9.55 \pm 0.61$ & $14.09 \pm 0.89$ & $0.001^{b}$ \\
\hline H.C (cm) & $36.08 \pm 1.88$ & $31.08 \pm 1.88$ & $35.08 \pm 1.13$ & $0.01^{\mathrm{a}}$ \\
\hline Apgar at $1 \mathrm{~min}$ & $2.8 \pm 0.3$ & $4.8 \pm 0.5$ & $5.2 \pm 0.1$ & NS \\
\hline Apgar at 5 min & $5.6 \pm 0.6$ & $8.3 \pm 0.4$ & $9.1 \pm 0.6$ & NS \\
\hline Adiponectine $(\mu \mathrm{g} / \mathrm{ml})$ & $23.36 \pm 5.86$ & $28.2 \pm 6.98$ & $36.35 \pm 10.55$ & $0.001^{b}$ \\
\hline Leptin (ng/ml) & $22.91 \pm 3.73$ & $4.48 \pm 3.22$ & $17.02 \pm 3.01$ & $0.001^{b}$ \\
\hline Insulin ( $\mu \mathrm{lU} / \mathrm{ml})$ & $67.13 \pm 8.77$ & $50.92 \pm 9.10$ & $55.0 \pm 9.19$ & $0.01^{\mathrm{a}}$ \\
\hline Glucose (mmol/L) & $4.64 \pm 0.65$ & $4.01 \pm 0.86$ & $4.21 \pm 0.07$ & NS \\
\hline
\end{tabular}

Data is presented as $\mathrm{n}(\%)$ for frequencies and mean \pm S.D. for normal continuous variables. ${ }^{\mathrm{a}}$ Significant, ${ }^{\mathrm{b}}$ highly significant, NS not significant. HIE Hypoxic Ischemic Encephalopathy, AGA Appropriate for gestational age, SGA small for gestational age, M/f male/female, NFD/CS normal vaginal delivery/cesarean section 
Table 2 Circulating levels of adiponectin, leptin, insulin and glucose in HIE and Non-HIE at birth, 2nd, 6th days

\begin{tabular}{|c|c|c|c|c|c|}
\hline Item & & At birth & Day 2 & Day 6 & p-value \\
\hline \multirow[t]{2}{*}{ Adiponectine $(\mu \mathrm{g} / \mathrm{ml})$} & HIE & $23.36 \pm 5.86$ & $23.27 \pm 4.93$ & $23.03 \pm 5.7$ & $P<0.01^{a}$ \\
\hline & Non HIE & $32.64 \pm 9.91$ & $29.22 \pm 6.78$ & $26.4 \pm 4.98$ & \\
\hline \multirow[t]{2}{*}{ Leptin (ng/ml) } & HIE & $22.91 \pm 3.73$ & $22.72 \pm 4.73$ & $22.47 \pm 3.13$ & $P<0.001^{b}$ \\
\hline & Non HIE & $11.32 \pm 7.01$ & $9.98 \pm 8.11$ & $9.13 \pm 7.22$ & \\
\hline \multirow[t]{2}{*}{ Insulin $(\mu \mathrm{IU} / \mathrm{ml})$} & HIE & $67.13 \pm 8.77$ & $67.33 \pm 8.77$ & $67.49 \pm 8.77$ & $P<0.01^{a}$ \\
\hline & Non HIE & $53.14 \pm 9.30$ & $54.06 \pm 4.02$ & $56.18 \pm 4.33$ & \\
\hline
\end{tabular}

${ }^{\mathrm{a}}$ Significant, ${ }^{b}$ highly significant, NS not significant. HIE Hypoxic Ischemic Encephalopathy, Non-HIE Non-Hypoxic Ischemic Encephalopathy

during the first week of life with adiponectin level was the most affected one, while between group variance revealed that neonates with HIE were the most affected group followed by AGA group and lastly SGA as regards these hormonal changes (Tables 3 \& 4).

Linear regression analysis was performed using adiponectin as a dependent variable and all parameters measured as independent variables and the body weight and BMI followed by leptin levels were the most predictor variables for adiponectin $(R=-0.47 ; P=0.03, R=-0.38$; $P=0.04$ and $R=-0.27 ; P=0.14$ respectively) (Not shown in the results).

In all studied groups, the serum adiponectin level was positively correlated at birth with body weight $(r=$ $0.509, p<0.001)$, length $(r=0.424, p<0.01)$, BMI $(r=$ $0.460, p<0.001)$ and leptin levels $(r=0.355, p<0.04)$ but it was not correlated with the insulin level $(r=$ $0.160, p=0.277)$. In neonates with HIE, the serum adiponectin level was not correlated with body weight $(r=-0.056, p=0.816)$, BMI $(r=-0.271, p=0.247)$, leptin level $(r=0.122, p=0.609)$, or insulin level $(r=0.444$, $p<0.06)$.) (Table 5).

Serum leptin level was positively correlated at birth with body weight $(r=0.935, p<0.001)$, height $(r=0.818$, $p<0.001)$ and BMI $(r=0.918, p<0.001)$ but it was not correlated with the insulin level $(r=0.105, p=0.479)$ in all studied groups (Table 5).

\section{Discussion}

Analysis of adipose tissue histology of fat cells in newborns demonstrated two populations of cells in the adipose tissue: small cells that do not contain fat and larger cells that contain fat but are small in their diameter compared with adult fat cells [23]. Adiponectin seems to be produced and secreted exclusively by adipocytes and an increase in fat mass leads to down-regulation of adiponectin in adults [24].

Sivan et al. 2003 [25] suggested that neonatal adiponectin is derived mainly from fetal tissues and not from maternal or placental tissues. Therefore, the possibility that a facilitated transport of adiponectin from the maternal blood through the placenta is responsible for the high levels of the hormone in cord blood seems unlikely.

In this study serum adiponectin concentration was significantly lower in neonates with HIE than normal healthy neonates reflecting the injurious effect of hypoxia on the functions of the adipose tissues like other tissues as myocardium, liver, renal and central nervous system [17, 18]. Pardo et al. 2004 [26] speculated that some endocrine, paracrine, and autocrine factor(s) that are responsible for the known suppression of adiponectin production could be reduced in newborns in comparison to older children. Kamoda et al. 2004 [27] found that the levels of serum adiponectin were significantly higher in all newborn neonates than in healthy children.

Table 3 Circulating levels of adiponectin, leptin, insulin and glucose in HIE and AGA at birth, 2nd and 6th days

\begin{tabular}{|c|c|c|c|c|c|c|}
\hline \multirow[t]{2}{*}{ Item } & \multicolumn{2}{|l|}{ Birth } & \multicolumn{2}{|l|}{ 2nd day } & \multicolumn{2}{|l|}{ 6th day } \\
\hline & $\mathrm{HIE}$ & AGA & HIE & AGA & HIE & AGA \\
\hline \multirow[t]{2}{*}{ Adiponectine $(\mu \mathrm{g} / \mathrm{ml})$} & $23.36 \pm 5.86$ & $36.35 \pm 10.55$ & $23.27 \pm 4.93$ & $31.33 \pm 9.98$ & $23.03 \pm 5.77$ & $28.56 \pm 9.38$ \\
\hline & $P<0.00^{b}$ & & $P<0.00^{b}$ & & $P<0.03^{\mathrm{a}}$ & \\
\hline \multirow[t]{2}{*}{ Leptin (ng/ml) } & $22.91 \pm 3.73$ & $17.02 \pm 3.01$ & $22.72 \pm 4.73$ & $15.98 \pm 3.01$ & $22.47 \pm 3.13$ & $14.91 \pm 2.90$ \\
\hline & $P<0.00^{\mathrm{b}}$ & & $P<0.00^{b}$ & & $P<0.00^{b}$ & \\
\hline \multirow[t]{2}{*}{ Insulin $(\mu \mathrm{lU} / \mathrm{ml})$} & $67.13 \pm 8.77$ & $55.0 \pm 9.19$ & $67.33 \pm 8.77$ & $56.98 \pm 3.01$ & $67.49 \pm 8.77$ & $60.4 \pm 11.0$ \\
\hline & $P<0.00^{b}$ & & $P<0.00^{b}$ & & $P<0.00^{b}$ & \\
\hline \multirow[t]{2}{*}{ Glucose (mmol/L) } & $4.64 \pm 0.65$ & $4.21 \pm 0.07$ & $4.33 \pm 0.06$ & $4.53 \pm 0.38$ & $4.61 \pm 0.11$ & $4.36 \pm 0.45$ \\
\hline & NS & & NS & & NS & \\
\hline
\end{tabular}


Table 4 Linear regression analysis of the studied hormones in different studied groups during the first week of life

\begin{tabular}{|c|c|c|c|c|c|}
\hline \multirow[t]{2}{*}{ Item } & & \multicolumn{2}{|c|}{ Confidence interval for B } & \multirow{2}{*}{$\begin{array}{l}\text { Standardized Coefficients } \\
\text { B }\end{array}$} & \multirow[t]{2}{*}{$P$ value } \\
\hline & & Lower Bound & upper Bound & & \\
\hline \multirow[t]{3}{*}{ Non HIE AGA neonate } & Adiponectin & 0.1 & 0.015 & 0.274 & $0.009^{b}$ \\
\hline & Leptin & 0.33 & 0.045 & 2.6 & $0.011^{\mathrm{a}}$ \\
\hline & Insulin & 0.002 & 0.09 & 0.214 & $0.04^{\mathrm{a}}$ \\
\hline \multirow[t]{3}{*}{ Non HIE SGA neonate } & Adiponectin & 0.147 & 0.005 & 0.213 & 0.07 \\
\hline & Leptin & 0.27 & 0.06 & 0.15 & 0.21 \\
\hline & Insulin & 0.05 & 0.06 & 0.016 & 0.9 \\
\hline \multirow[t]{3}{*}{ HIE neonates } & Adiponectin & 0.2 & 0.022 & 0.374 & $0.001^{b}$ \\
\hline & Leptin & 0.13 & 0.025 & 1.6 & $0.01^{\mathrm{a}}$ \\
\hline & Insulin & 0.02 & 0.09 & 0.224 & $0.03^{\mathrm{a}}$ \\
\hline
\end{tabular}

${ }^{a}$ Significant, ${ }^{b}$ highly significant, NS not significant. HIE Hypoxic Ischemic Encephalopathy, AGA Appropriate for gestational age, SGA small for gestational age

In this study, the serum adiponectin level was positively correlated at birth with body weight, length and BMI but not with insulin levels and these results are in agreement with many others $[28,29]$. This may be due to a lack of negative feedback on adiponectin production resulting from a lack of adipocyte hypertrophy and a low percentage of body fat [30].

In this study, the mean value of serum adiponectin was significantly lower in SGA than in AGA neonates and this may be due to presence of a lower amount of a brown adipose tissue in SGA neonates [27].

In neonates with HIE, the serum adiponectin level was not correlated with body weight, BMI, leptin or insulin levels and this may be attributed to the disturbed mechanisms controlling the growth factors release either from the adipose tissues or from other organs $[17,18]$.

Leptin is synthesized and secreted in the placenta by the mother and by the fetus [22]. It is detectable from the second trimester and its level increases from the middle of the third trimester towards term, according to the stores of fetal adipose tissue [31, 32].

In this study, leptin and insulin concentrations were significantly higher in neonates with HIE than normal healthy neonates denoting the leptin and insulin insensitivity in these neonates which may be due to the effect of hypoxia and/or ischemia on the peripheral tissues resistance. These results are in consistence with Tzschoppe et al. 2011 [31].

Leptin acts as an endogenous mediator of neuroprotection during cerebral ischemia and exogenous leptin administration protects against ischemic neuronal injury in vitro and in vivo $[33,34]$. Leptin and IL-1beta treatment improves neuronal density and decreases apoptosis in the newborn rat and experimental animals with hypoxic-ischemic brain injury $[35,36]$.

The serum leptin level was positively correlated at birth with body weight, height and BMI but not with insulin level in all studied groups and these results are in accordance with many other studies [37, 38]. In this study we found leptin levels to be higher in AGA neonates with respect to SGA neonates at birth and this is in accordance with others $[28,29]$. The previous results were anticipated since leptin is mainly synthesized by the white adipose tissue and released in the circulation proportionally to the amount of body fat mass $[39,40]$.

$\mathrm{Ng}$ et al. 2000 [41] suggested that the low leptin levels in extremely preterm neonates may be a physiologic advantage as body energy utilization can be minimized and nutritional reserves conserved for subsequent growth and development.

Our results revealed that in neonates with HIE, the serum leptin levels were not correlated with body weight, BMI or insulin level after birth denoting the disturbed mechanisms essential for metabolic control.

In this study, serum insulin level was higher in neonates with HIE than normal healthy neonates and it was not correlated with serum adiponectin level and these results are in agreement with others [42, 43].

Iniguez et al. 2004 [43] found no correlations between adiponectin and insulin levels at two years of life, However, Mami et al. 2008 [42] reported negative correlation between adiponectin and insulin at birth and Yamamoto et al. 2002 [44] reported negative correlations between adiponectin and insulin in adults and that serum adiponectin concentration predicts subsequent changes in insulin resistance. This difference with our results may be due to the small sample size, age group of studied patients or the methodology of the study.

In this study, there was no significant difference between SGA and AGA neonates regarding serum insulin levels at birth. This is in agreement with MartinezCordero et al. 2006 [28] and with other studies reported that the cord blood c-peptide levels, a proxy for fetal pancreatic insulin secretion, were correlated positively with the birth weight $[45,46]$, but not with Yajnik et al. 
Table 5 Correlations between adiponectin and leptin levels and other studied parameters

\begin{tabular}{|c|c|c|c|c|c|c|}
\hline \multirow[t]{2}{*}{ Item } & \multicolumn{2}{|l|}{$\mathrm{HIE}$} & \multicolumn{2}{|l|}{ Non-HIE AGA } & \multicolumn{2}{|l|}{ Non-HIE SGA } \\
\hline & Adiponectin & Leptin & Adiponectin & Leptin & Adiponectin & Leptin \\
\hline \multirow{2}{*}{$\begin{array}{l}\text { Gestational } \\
\text { age (weeks) }\end{array}$} & $r=-0.15$ & $r=0.42$ & $r=0.70$ & $r=0.64$ & $r=0.40$ & $r=0.47$ \\
\hline & $p=0.71$ & $p=0.32$ & $p<0.001^{b}$ & $p<0.01^{a}$ & $p<0.01^{\mathrm{a}}$ & $p<0.01^{\mathrm{a}}$ \\
\hline \multirow[t]{2}{*}{ Weight (Kg) } & $r=-0.05$ & $r=0.36$ & $r=0.60$ & $r=0.93$ & $r=0.50$ & $r=0.73$ \\
\hline & $p=0.81$ & $p=0.11$ & $p<0.01^{a}$ & $p<0.001^{b}$ & $p<0.01^{\mathrm{a}}$ & $p<0.01^{\mathrm{a}}$ \\
\hline \multirow[t]{2}{*}{ Length (cm) } & $r=-0.23$ & $r=0.31$ & $r=0.52$ & $r=0.81$ & $r=0.42$ & $r=0.61$ \\
\hline & $p=0.96$ & $p=0.18$ & $p<0.01^{\mathrm{a}}$ & $p<0.01^{\mathrm{a}}$ & $p<0.01^{b}$ & $p<0.01^{\mathrm{a}}$ \\
\hline \multirow[t]{2}{*}{ BMI (kg/m2) } & $r=-0.27$ & $r=0.22$ & $r=0.66$ & $r=0.91$ & $r=0.46$ & $r=0.71$ \\
\hline & $p=0.24$ & $p=0.350$ & $p<0.01^{a}$ & $p<0.001^{b}$ & $p<0.001^{b}$ & $p<0.01^{\mathrm{a}}$ \\
\hline \multirow{2}{*}{$\begin{array}{l}\text { Insulin ( } \mu \mid \mathrm{U} / \\
\mathrm{ml})\end{array}$} & $r=0.44$ & $r=0.31$ & $r=0.26$ & $r=0.30$ & $r=0.16$ & $r=0.10$ \\
\hline & $p=0.06$ & $p=0.17$ & $p=0.27$ & $p=0.47$ & $p=0.27$ & $p=0.47$ \\
\hline \multirow{2}{*}{$\begin{array}{l}\text { Adiponectine } \\
(\mu \mathrm{g} / \mathrm{ml})\end{array}$} & -二- & $r=0.12$ & -二-—— & $r=0.55$ & -———- & $r=045$ \\
\hline & & $p=0.60$ & & $p<0.0^{\mathrm{a}}$ & & $p<0.02^{\mathrm{a}}$ \\
\hline \multirow[t]{2}{*}{ Leptin (ng/ml) } & $r=0.12$ & -二- & $r=0.55$ & -二- - & $r=0.35$ & -—— \\
\hline & $p=0.60$ & & $p<0.04^{\mathrm{a}}$ & & $p<0.04^{\mathrm{a}}$ & \\
\hline
\end{tabular}

'Significant, ${ }^{b}$ highly significant, NS not significant. HIE Hypoxic Ischemic Encephalopathy, AGA Appropriate for gestational age, SGA small for gestational age 
2002 [47] who reported that in Indian neonates, despite their lower birth weight, have hyperinsulinemia.

In this study intra-group variance revealed that serum levels of adiponectin, leptin and insulin were significantly changed during the first week of life with adiponectin level was the most affected one, while between group variance revealed that neonates with HIE were the most affected group followed by AGA group and lastly SGA as regards these hormonal changes.

As expected, in this study all neonatal anthropometric measurements were higher in neonates of AGA than SGA group.

Measurement of the maternal levels of these hormones and correlations between them and neonatal serum levels as well as follow-up of these levels for longer periods (for example for 1 or 2 years) were limitation for this work which need more financial support and large number of patients.

These findings have further clinical implications for pediatricians to understand the effect of hypoxia and or ischemia on different organs of the body including adipose tissue and the different mechanisms controlling its functions.

\section{Conclusions}

Neonates with HIE had lower serum levels of adiponectin and higher serum levels of leptin and insulin than normal healthy neonates at birth and during the early post natal period. SGA neonates had lower serum levels of adiponectin and leptin but not insulin levels than AGA neonates. Positive significant correlations between adiponectin, leptin, body weight and body mass indices were present in normal healthy neonates but not in neonates with HIE reflecting the effect of hypoxia on the regulatory mechanisms controlling the adipose tissue functions.

\section{Competing interests}

There are no any financial or non-financial competing interests to declare in relation to this manuscript.

\section{Authors' contributions \\ $A E$ participated in the design of the study, analysis and interpretation of data and revised the statistics and final draft of the manuscript. KN and TS conceived of the study, carried out its designing, coordinated the implementation, helped to perform the statistical analysis and drafted the manuscript. GA participated in the conception and design of the study, collected the data and performed the statistical analyses. Both of AE and GA were responsible for follow up of patients and interpretation of laboratory data of them. EF and EE participated in the conception and design of the study, participated in acquisition of data and revised the manuscript. All authors read and approved the final manuscript.}

\section{Acknowledgements}

Authors wish to thank all staff of the NICU of Minia university hospital for their assistance during the data collection. We also wish to thank Dr. Ahmed Aly, Lecturer of Public health and Statistics for his effort to complete the statistics of this work.

\section{Author details}

${ }^{1}$ Pediatric Department, Faculty of Medicine, Minia University, Minya, Egypt. ${ }^{2}$ Biochemistry Department, Faculty of Medicine, Minia University, Minya, Egypt. ${ }^{3}$ Clinical pathology Department, Faculty of Medicine, Assuit University, Assuit, Egypt.

Received: 27 March 2015 Accepted: 30 November 2015

Published online: 01 December 2015

\section{References}

1. Graham EM, Ruis A, Hartman AL, Northington FJ, Fox HE. "A systematic review of the role of intrapartum hypoxia-ischemia in the causation of neonatal encephalopathy,". Am J Obstet Gynecol. 2008;199(6):587-95.

2. van Handel M, Swaab H, de Vries LS, Jongmans MJ. Long-term cognitive and behavioral consequences of neonatal encephalopathy following perinatal asphyxia: a review. Eur J Pediatr. 2007;166(7):645-54.

3. Lawn J, Shibuya K, Stein C. No cry at birth: global estimates of intrapartum stillbirths and intrapartum-related neonatal deaths. Bull World Health Organ. 2005;83(6):409-17.

4. Bozzola E, Meazza C, Arvigo M, Travaglino P, Pagani S, Stronati M, et al. Role of adiponectin and leptin on body development in neonates during the first year of life. Ital J Pediatr. 2010;36:26.

5. Monteiro POA, Victora CG. Rapid growth in infancy and childhood and obesity in the later life-a systematic review. Obes Rev. 2005;6:143-54.

6. Pittas AG, Joseph NA, Greenberg AS. Adipocytokines and insulin resistance. J Clin Endocrinol Metab. 2004;89:447-52.

7. Volberg V, Heggeseth B, Harley K, Huen K, Yousefi P, Davé V, et al. Adiponectin and leptin trajectories in Mexican-American children from birth to 9 years of age. PLoS One. 2013;8(10):e77964

8. Nishimura R, Sano H, Matsudaira T, Morimoto A, Miyashita Y, Shirasawa T, et al. Changes in body mass index, leptin and adiponectin in Japanese children during a three-year follow-up period: a population-based cohort study. Cardiovasc Diabetol. 2009;3(8):30.

9. Lindsay RS, Walker JD, Havel PJ, Hamilton BA, Calder AA, Johnstone FD. Scottish multicentre study of diabetes pregnancy. Adiponectin is present in cord blood but is unrelated to birth weight. Diabetes Care. 2003;26(8):2244-9.

10. Weyer C, Funahashi T, Tanaka S, Hotta K, Matsuzawa Y, Pratley RE, et al. Hypoadiponectinemia in obesity and type 2 diabetes: close association with insulin resistance and hyperinsulinemia. J Clin Endocrinol Metab. 2001;86:1930-5.

11. Hermansson $\mathrm{H}$, Hoppu U, Isolauri E. Elective caesarean section is associated with low adiponectin levels in cord blood. Neonatology. 2014;105(3):172-4

12. Valūnienẻ $M$, Verkauskienė $R$, Boguszewski $M$, Dahlgren J, Lašienė $D$, Lašas $L$, et al. Leptin levels at birth and in early postnatal life in smalland appropriate-for-gestational-age neonates. Medicina (Kaunas). 2007; 43(10):784-91.

13. Harley KG, Aguilar Schall R, Chevrier J, Tyler K, Aguirre H, Bradman A, et al. Prenatal and postnatal bisphenol a exposure and body mass index in childhood in the CHAMACOS cohort. Environ Health Perspect. 2013;121(4):514-20.

14. Wen X, Kleinman K, Gillman MW, Rifas-Shiman SL, Taveras EM. Childhood body mass index trajectories: modeling, characterizing, pairwise correlations and socio-demographic predictors of trajectory characteristics. BMC Med Res Methodol. 2012;12:38.

15. Shklyaev S, Aslanidi G, Tennant M, Prima V, Kohlbrenner E, Kroutov V, et al. Sustained peripheral expression of transgene adiponectin offsets the development of diet-induced obesity in rats. Proc Natl Acad Sci U S A. 2003; 100(24):14217-22.

16. Hassink SG, Sheslow DV, de Lancey E, Opentanova I, Considine RV, Caro JF. Serum leptin concentrations in children with obesity: relationship to gender and development. Pediatrics. 1996;98:201-3.

17. Shah P, Riphagen S, Beyene J, Perlman M. Multiorgan dysfunction in infants with post-asphyxial hypoxic-ischaemic encephalopathy. Arch Dis Child Fetal Neonatal Ed. 2004;89:F152-5.

18. Martin-Ancel A, Garcia-Alix A, Gaya F, Cabanas F, Burgueros M, Quero J. Multiple organ involvement in perinatal asphyxia. J Pediatr. 1995; 127:786-93.

19. [Guideline] American Academy of Pediatrics. Relation between perinatal factors and neurological outcome. In: Guidelines for Perinatal Care. 3rd ed. Elk Grove Village, III: American Academy of Pediatrics; 1992:221-234.

20. [Guideline] Committee on fetus and newborn, American Academy of Pediatrics and Committee on obstetric practice, American College of 
Obstetrics and Gynecology. Use and abuse of the APGAR score. Pediatr. 1996. 98:141-142.

21. Evagelidou EN, Giapros VI, Challa AS, Kiortsis DN, Tsatsoulis AA, Andronikou SK. Serum adiponectin levels, insulin resistance, and lipid profile in children born small for gestational age are affected by the severity of growth retardation at birth. Eur J Endocrinol. 2007;156(2):271-77.

22. Hoggard N, Haggarty P, Thomas L, Lea RG. Leptin expression in placenta and fetal tissues: does leptin have a functional role? Biochem Soc Trans. 2001;29:57-63.

23. Koester-Weber T, Valtueña J, Breidenassel C, Beghin L, Plada M, Moreno S, et al. Reference values for leptin, cortisol, insulin and glucose, among European adolescents and their association with adiposity: the HELENA study. Nutr Hosp. 2014;30(5):1181-90.

24. Miras M, Ochetti M, Martín S, Silvano L, Sobrero G, Castro L, et al. Serum levels of adiponectin and leptin in children born small for gestational age: relation to insulin sensitivity parameters. J Pediatr Endocrinol Metab. 2010; 23(5):463-71.

25. Sivan E, Mazaki-Tovi S, Pariente C, Efraty Y, Schiff E, Hemi R, et al. Adiponectin in human cord blood: relation to fetal birth weight and gender. J Clin Endocrinol Metab. 2003;88(12):5656-60.

26. Pardo IM, Geloneze B, Tambascia MA, Barros-Filho AA Hyperadiponectinemia in newborns: relationship with leptin levels and birth weight. Obes Res. 2004;12(3):521-24.

27. Kamoda T, Saitoh H, Saito M, Sugiura M, Matsui A. Serum adiponectin concentrations in newborn neonates in early postnatal life. Pediatr Res. 2004;56(5):690-93.

28. Martinez-Cordero C, Amador-Licona N, Guizar-Mendoza JM, HernandezMendez J, Ruelas-Orozco G. Body fat at birth and cord blood levels of insulin, adiponectin, leptin, and insulin-like growth factor-l in small for gestational age neonates. Arch Med Res. 2006;37:490-4.

29. Strocchio L1, Bozzola E, Cerbo RM, Meazza C, Travaglino P, Pagani S, et al. Changes in circulating levels of adiponectin and leptin in children during the first two years of life. Minerva Pediatr. 2007;59(6):739-44.

30. Nakano Y, Itabashi K, Sakurai M, Aizawa M, Dobashi K, Mizuno K. Preterm neonates have altered adiponectin levels at term-equivalent age even if they do not present with extrauterine growth restriction. Horm Res Paediatr. 2013:80(3):147-53.

31. Tzschoppe A, Struwe E, Rascher W, Dörr HG, Schild RL, Goecke TW, et al. Intrauterine growth restriction (IUGR) is associated with increased leptin synthesis and binding capability in neonates. Clin Endocrinol (Oxf). 2011; 74(4):459-66.

32. Mantzoros CS, Sweeney L, Williams CJ, Oken E, Kelesidis T, Rifas-Shiman SL, et al. Maternal diet and cord blood leptin and adiponectin concentrations at birth. Clin Nutr. 2010;29:622-6.

33. Valerio A, Dossena M, Bertolotti P, Boroni F, Sarnico I, Faraco G, et al. Leptin is induced in the ischemic cerebral cortex and exerts neuroprotection through NF-kappaB/c-Rel-dependent transcription. Stroke. 2009;40(2):610-7.

34. Corina L, David AA, Megan A, Allison AA, Devin CK, Alison GP, et al. Sexspecific associations between placental leptin promoter DNA methylation and infant neurobehavior. Psychoneuroendocrinology. 2014;40:1-9.

35. Kumral A, Yesilirmak DC, Sozmen S, Ergur BU, Tugyan K, Ozbal S, et al. Effect of leptin treatment on neonatal hypoxic-ischemic brain injury. J Matern Fetal Neonatal Med. 2012;25(2):141-6.

36. Wang CH, Wang WT, Cheng SY, Hung WT, Wu TL, Hsueh CM. Leptin and interleukin-1 beta modulate neuronal glutamate release and protect against glucose-oxygen-serum deprivation. Curr Neurovasc Res. 2010;7(3):223-37.

37. Shroff MR, Holzman C, Tian Y, Evans RW, Sikorskii A. Mid-pregnancy maternal leptin levels, birthweight for gestational age and preterm delivery. Clin Endocrinol (Oxf). 2013;78(4):607-13.

38. Uebel K, Pusch K, Gedrich K, Schneider KT, Hauner H, Bader BL. Effect of maternal obesity with and without gestational diabetes on offspring subcutaneous and preperitoneal adipose tissue development from birth up to 1-year. BMC Pregnancy Childbirth. 2014;11(14):138

39. Tejero ME, Cai G, Göring HH, Diego V, Cole SA, Bacino CA, et al. Linkage analysis of circulating levels of adiponectin in Hispanic children. Int J Obes (Lond). 2007;31(3):535-42.

40. Tomoo O, Shigeru T, Nobuhiko N, Kayo Y, Yukihiro U, Shigeharu H, et al. Early postnatal alteration of body composition in preterm and small-forgestational-age infants: implications of catch-up fat. Pediatric Research 2015; 77:136-142.
41. Ng PC, Lam CW, Lee CH, Wong GW, Fok TF, Chan IH, et al. Leptin and metabolic hormones in preterm newborns. Arch Dis Child Fetal Neonatal Ed. 2000;83:198-202.

42. Mamì C, Marseglia L, Manganaro R, Saitta G, Martino F, Gargano R, et al. Serum levels of resistin and its correlation with adiponectin and insulin in healthy full term neonates. Early Hum Dev. 2009;85(1):37-40.

43. Iñiguez G, Soto N, Avila A, Salazar T, Ong K, Dunger D, et al. Adiponectin levels in the first two years of life in a prospective cohort: relations with weight gain, leptin levels and insulin sensitivity. J Clin Endocrinol Metab. 2004;89(11):5500-503.

44. Yamamoto Y, Hirose H, Saito I, Tomita M, Taniyama M, Matsubara K, et al. Correlation of the adipocyte-derived protein adiponectin with the insulin resistance index and serum high-density lipoprotein-cholesterol, independent of body mass index, in the Japanese population. Clin Sci (Lond). 2002;103(2):137-42.

45. Wang LJ, Mu SC, Cheng I, Chen YL, Chen BF, Jow GM. Decreased leptin concentration in neonates is associated with enhanced postnatal growth during the first year. Kaohsiung J Med Sci. 2012;28(10):521-5.

46. Georgios V, Dimitrios CP, Alexandra M, Vassilios B, Efthymios K, loannis $P$, et al. First trimester maternal BMl is a positive predictor of cord blood c-peptide levels while maternal visfatin levels is a negative predictor of birth weight. HORMONES. 2014;13(1):87-94.

47. Yajnik CS, Lubree HG, Rege SS, Naik SS, Deshpande JA, Deshpande SS, et al. Adiposity and hyperinsulinemia in Indians are present at birth. J Clin Endocrinol Metab. 2002;87:5575-80.

\section{Submit your next manuscript to BioMed Central and we will help you at every step:}

- We accept pre-submission inquiries

- Our selector tool helps you to find the most relevant journal

- We provide round the clock customer support

- Convenient online submission

- Thorough peer review

- Inclusion in PubMed and all major indexing services

- Maximum visibility for your research

Submit your manuscript at www.biomedcentral.com/submit 